\title{
Risk assessment of temperature and air pollutants on hospitalizations for mental and behavioral disorders in Curitiba, Brazil
}

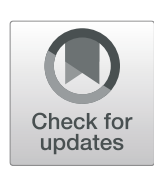

lara da Silva ${ }^{1 *}$ (D) Daniela Sanches de Almeida ${ }^{1,2}$, Elizabeth Mie Hashimoto ${ }^{1}$ and Leila Droprinchinski Martins ${ }^{1 *}$

\begin{abstract}
Background: Extreme ambient temperatures and air quality have been directly associated with various human diseases from several studies around the world. However, few analyses involving the association of these environmental circumstances with mental and behavioral disorders (MBD) have been carried out, especially in developing countries such as Brazil.
\end{abstract}

Methods: A time series study was carried out to explore the associations between daily air pollutants $\left(\mathrm{SO}_{2}, \mathrm{NO}_{2}, \mathrm{O}_{3}\right.$, and $\mathrm{PM}_{10}$ ) concentrations and meteorological variables (temperature and relative humidity) on hospital admissions for mental and behavioral disorders for Curitiba, Brazil. Daily hospital admissions from 2010 to 2016 were analyzed by a semi-parametric generalized additive model (GAM) combined with a distributed lag non-linear model (DLNM).

Results: Significant associations between environmental conditions $\left(10 \mathrm{\mu g} / \mathrm{m}^{3}\right.$ increase in air pollutants and temperature $\left.{ }^{\circ} \mathrm{C}\right)$ and hospitalizations by MBD were found. Air temperature was the environmental variable with the highest relative risk (RR) at 0-day lag for all ages and sexes analyzed, with RR values of 1.0182 (95\% Cl: 1.0009-1.0357) for men, and 1.0407 (95\% Cl: 1.0230-1.0587) for women. Ozone exposure was a risk for all women groups, being higher for the young group, with a RR of 1.0319 (95\% Cl: 1.0165-1.0483). Elderly from both sexes were more susceptible to temperature variability, with a RR of 1.0651 (95\% Cl: 1.0213-1.1117) for women, and 1.0215 (95\% Cl: 1.0195-1.0716) for men.

Conclusions: This study suggests that temperatures above and below the thermal comfort threshold, in addition to high concentrations of air pollutants, present significant risks on hospitalizations by MBD; besides, there are physiological and age differences resulting from the effect of this exposure.

Keywords: Air quality, Mental diseases, Distributed lag non-linear model, Relative risk

\section{Highlights}

The highest relative risks occurred in the same day of the exposure $(\operatorname{lag}=0)$.

Women are more affected by air pollutants and temperature variability than men.

Elderly from both sexes are more vulnerable to temperature variability.

\footnotetext{
* Correspondence: iara@alunos.utfpr.edu.br; leilamartins@utfpr.edu.br ${ }^{1}$ Federal University of Technology - Paraná, Av. dos Pioneiros, 3131, Londrina, PR 86036-370, Brazil

Full list of author information is available at the end of the article
}

Ozone exposure is a risk for women and higher for young group with MBD.

\section{Background}

There are several strong evidences concerning the negative impacts of air pollution and extreme temperature on human health [1-3]. The complex mixture of chemical substances in polluted air associated with meteorological variables imposes various damages on circulatory and respiratory human system, as well as causes aggravation of diseases [4]. In addition, more recently, negative effects of

(c) The Author(s). 2020 Open Access This article is licensed under a Creative Commons Attribution 4.0 International License, which permits use, sharing, adaptation, distribution and reproduction in any medium or format, as long as you give appropriate credit to the original author(s) and the source, provide a link to the Creative Commons licence, and indicate if changes were made. The images or other third party material in this article are included in the article's Creative Commons licence, unless indicated otherwise in a credit line to the material. If material is not included in the article's Creative Commons licence and your intended use is not permitted by statutory regulation or exceeds the permitted use, you will need to obtain permission directly from the copyright holder. To view a copy of this licence, visit http://creativecommons.org/licenses/by/4.0/ The Creative Commons Public Domain Dedication waiver (http://creativecommons.org/publicdomain/zero/1.0/) applies to the data made available in this article, unless otherwise stated in a credit line to the data. 
these variables on mental disorders have been reported [58], including both Alzheimer's and Parkinson's diseases, which are progressive neurodegenerative diseases [9-14].

The mechanism of action is not completely understood, as well as the damages caused to immune system $[15,16]$. However, there are evidences that men and women present brain differences, which are related to biological factors (genetic and hormonal signals), physical environment, and sociocultural experiences [17, 18].

Epidemiological studies concerning the mental diseases associations with air pollution and meteorological variables have been conducted in the last years for short-term [6, 19-22] and long-term exposure [23, 24]. Almendra [20] found that the hospital admissions by mental disorders increase with high temperatures, and they pointed out that low temperatures can be a protective factor for Lisbon population [25]. observed associations between traffic-related air pollution and dementia incidence in Northern Sweden.

For developing countries located in the South Hemisphere the relationship between mental disorders, air pollution and temperature has been scarcely explored. In Brazil, epidemiological studies investigating the potential associations and their behavior for sex and age groups are non-existent [26]. conducted a study to examine the association between meteorological factors and suicide in São Paulo, Brazil, and they suggested that a temperature increase has a short-term effect on suicide. According to [27], the prevalence of dementia among Brazilian population ranged from 5.1 to $17.5 \%$, and the costs of dementia were estimated at US\$16,548.24 per patient/year [28]. In addition, in Brazil life expectancy is increasing, in 2018 it was around 75 years and for 2050 is estimated to be 80 years [29]. Therefore, with increasing life expectancy and the inversion of the country's age pyramid (around 9\% in 2018 to $22 \%$ in 2050 of elderly, $>65$ years), the fraction of population with dementia could be also increase, making it important to know the risks of environmental variables on development of these diseases, in order to provide subsidies for public health policies.

Thus, the aim of this study is to assess the short-term effects of daily environmental conditions $\left(\mathrm{SO}_{2}, \mathrm{NO}_{2}, \mathrm{O}_{3}\right.$ and $\mathrm{PM}_{10}$, temperature and relative humidity) on hospitalizations for mental and behavioral disorders in Curitiba city, Paraná state, Brazil. The data was analyzed by a semiparametric generalized additive model (GAM) combined with a distributed lag non-linear model (DLNM) for age groups, both sexes, and lag time (0-7 days).

\section{Methods}

\section{Location}

The city of Curitiba belongs to a regional political and socioeconomic division of the Parana state, in Brazil's southern region (Fig. 1). It is the main and most developed economic center of the state, and one of the most important in the country $[29,30]$. The city is highly urbanized and has around 1,917,185 inhabitants, of whom approximately $97 \%$ reside in urban areas. Curitiba has its main economic activity in commerce, therefore the vehicular emission is the predominant source of pollution [30]. Particular attention is paid to Curitiba because it is known for its urban planning, which has attracted worldwide attention as an example of sustainable urban development [31].

The altitude of the region is near $900 \mathrm{~m}$, with the climate classified according to W. Koeppen as tropical altitude of $\mathrm{Cfa}$ and $\mathrm{Cfb}$ [32]. The warmest months range from December to February with average daily temperatures between $17^{\circ} \mathrm{C}$ to $23^{\circ} \mathrm{C}$, when the solar incidence in the region is more pronounced, and there is a predominance of intertropical atmospheric systems. The coldest season is concentrated between the months of June and August, when polar atmospheric systems are more present and the solar incidence is lower, with temperatures average around $13{ }^{\circ} \mathrm{C}$. Rain occurs throughout the year, with less intensity in winter, which makes this season unfavorable for the dispersion of atmospheric pollutants [33-35].

\section{Data collection}

The daily average time series from 2010 to 2016 of $\mathrm{SO}_{2}$, $\mathrm{NO}_{2}, \mathrm{O}_{3}$ and $\mathrm{PM}_{10}$ concentrations, as well as temperature and relative humidity were analyzed in all hospital admissions for mental and behavioral disorders (MBD). The daily number of hospitalizations for primary diagnosis of MBD (Chapter V, codes F00-F99) classified according to the International Classification of Diseases (ICD 10) were compiled from the website of public Single System of Health (SUS), Department of Informatics (DATASUS) webpage (www.datasus.saude.gov.br), as shown in Table 1.

The meteorological variables and air pollutant concentrations were obtained from the public Environmental Institute of Paraná (IAP - in Portuguese Instituto Ambiental do Paraná, www.iap.pr.gov.br). Three urban air quality automatic stations, located in Curitiba city (Fig. 1), were considered to calculate the daily means from hourly concentrations of pollutants and meteorological variables. The stations used had at least $80 \%$ of valid data.

\section{Statistical method}

Firstly, a descriptive analysis was performed for the data. Then, the covariates were selected to compose the final analysis for each group by Stepwise method, which assists to identify the predictors to be inserted in the final model. The process verifies the significance of the explanatory variables by systematically adding the most significant variable or by removing the least significant 


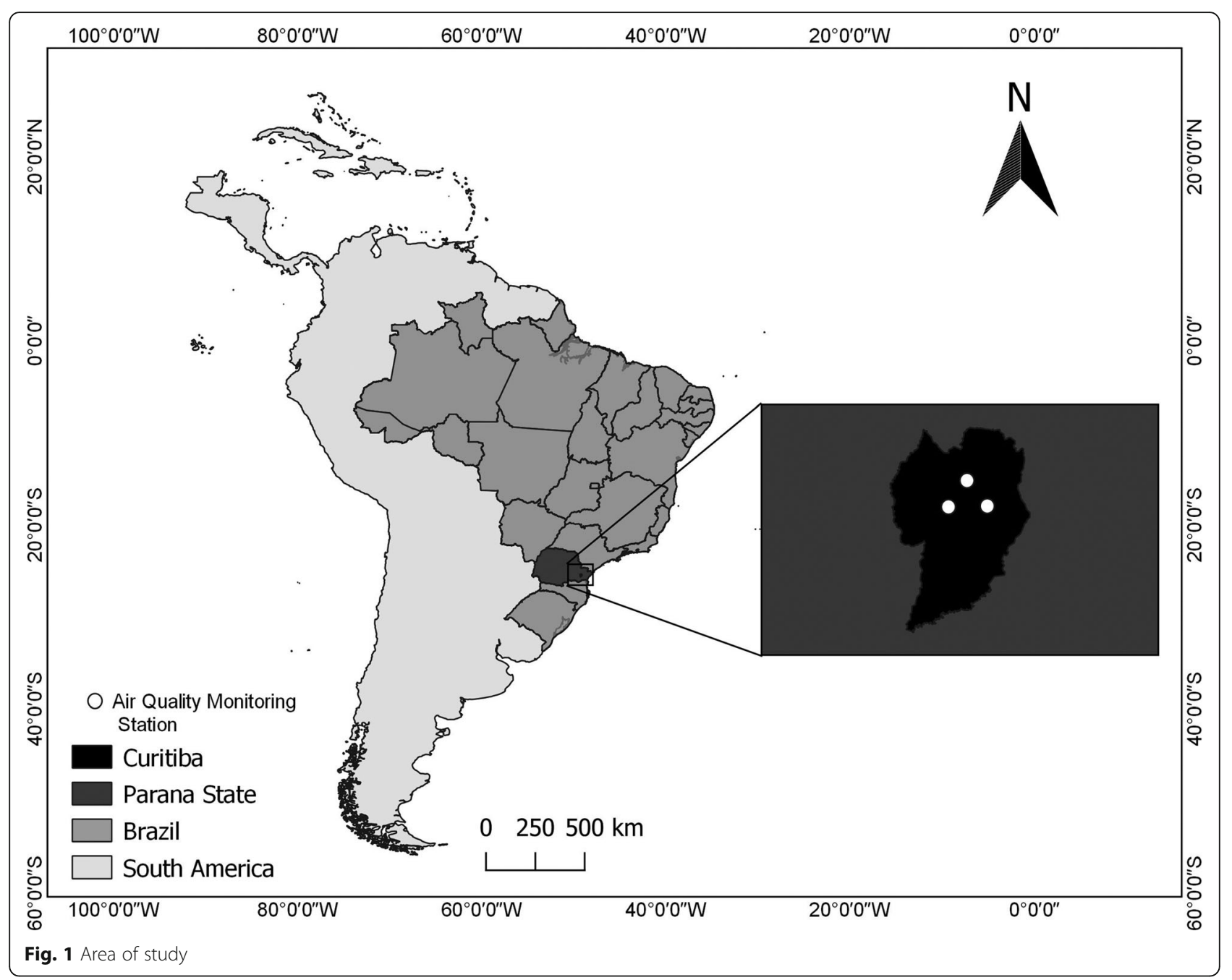

Table 1 International Classification of Disease (ICD 10) codes for mental disorders used in the present study

\begin{tabular}{|c|c|}
\hline ICD 10 & Description \\
\hline F00 - F09 & $\begin{array}{l}\text { Organic Mental Disorders, including Symptomatic Mental } \\
\text { Disorders }\end{array}$ \\
\hline$F 10-F 19$ & $\begin{array}{l}\text { Mental and behavioral disorders due to the use of } \\
\text { psychoactive substance }\end{array}$ \\
\hline$F 20-F 29$ & Schizophrenia, schizotypal disorders and delusional disorders \\
\hline$F 30-F 39$ & Mood Disorders [affective] \\
\hline$F 40-F 48$ & $\begin{array}{l}\text { Neurotic disorders, stress-related disorders and somatoform } \\
\text { disorders }\end{array}$ \\
\hline F50 - F59 & $\begin{array}{l}\text { Behavioral syndromes associated with physiological } \\
\text { dysfunctions and physical factors }\end{array}$ \\
\hline$F 60-F 69$ & Adult personality and behavior disorder \\
\hline$F 70-F 79$ & Mental retardation \\
\hline F80 - F89 & Psychological developmental disorders \\
\hline F90 - F98 & Psychological developmental disorders \\
\hline F99 & Mental disorder not specified \\
\hline
\end{tabular}

one during each step, with inference based on the significance level of $5 \%$ [36, 37]. All variables were tested and only those with statistical significance were included in the final model (see the supplementary material). The analysis was stratified by sex and age group as: young from 0 to 24 years old, adults from 25 to 59 years old, and elderly with 60 years or more. These groups were defined according to changes of physiological characteristics due to the aging of the organism [38-40].

It was used a generalized additive model (GAM) combined with a distributed lag non-linear model (DLNM), a modeling framework that can simultaneously represent non-linear exposure-response dependencies and delayed effects [41, 42]. The combined use of the DLNM model provides values of the effect of the event with $N$-day lag, also emphasizing the cumulative effect measurement during the period [41, 42]. For the assessment of short-term exposure to air pollutants and meteorological variables, the established delay was from 0 to 7 days [19, 43, 44].

Weekdays and holidays were added to the model as a factor variable with 7 levels (Monday to Sunday) in the 
case of days of the week, and a binary indicator $(0$ or 1) for the holidays, to soften the characteristics of hospitalizations concentrated on certain days of the week [33]. The meteorological and air quality variables, due to their seasonality, were modeled by natural cubic splines with 3 degrees of freedom $(d f)$ for pollutants and relative humidity, $5 d f$ for temperature and $7 d f$ per year for time space [19, 21, 43-48]. In this study, the number of the MBD is the random variable denoted by $Y_{i}(i=1, \ldots, n)$, and the distribution of $Y_{i}$ in a GAM may be any distribution belonging to the exponential family [49]. Among the GAM, two distributions were tested: Poisson and negative binomial, which are widely used distributions in epidemiological studies involving counting data. The latter one distribution have a parameter that corrects the overdispersion of the data, which is expected in this type of study $[19,33,50]$. It was also considered an extension of the Poisson distribution, called the quasi-Poisson model, including of a dispersion parameter [51]. For the systematic part [42, 52], the semiparametric model is given by:

$g\left(\mu_{i}\right)=\alpha+\sum_{j=1}^{6} s_{j}\left(x_{j i}\right)+\beta_{1}$ day $_{i}+\beta_{2}$ holy $_{i}+\beta_{3}$ time $, i=1, \ldots, n$,

where $E\left(Y_{i}\right)=\mu_{i}, g($.) is a logarithmic link function, $\alpha$ is the intercept, $s($.$) represents the natural cubic spline for$ non-linear predictor variables, $x_{j i}$ denotes the explanatory variables (daily mean temperature, relative humidity and pollutant concentrations), time refers to the effect of the temporal trend, day is the day of the week parameter and finally holy, which refers to holidays.

The relative risk (RR) with 95\% confidence interval (CI) of hospital admissions for MBD were calculated for significant variables $(p$-value $<0.05)$ for each age group to the cumulative effect of 0 to 7 days exposure. Statistical analyzes were performed using the statistical software R 3.5.3 with the "DLNM" package.

\section{Results}

\section{Exploratory analysis}

Table 2 presents descriptive statistics for all daily variables analyzed. Of the 5397 hospitalizations recorded in the study period (2010-2016), approximately 60\% were of men. On average, there were three daily hospital admissions by MBD. Regarding environmental conditions, the mean daily temperature was $22.4^{\circ} \mathrm{C}$, ranging from 5.9 to $35.0{ }^{\circ} \mathrm{C}$, the mean daily relative humidity was $81.8 \%$, and the mean daily concentrations for $\mathrm{SO}_{2}, \mathrm{NO}_{2}$, $\mathrm{O}_{3}$ and $\mathrm{PM}_{10}$ were of $0.53 \mu \mathrm{g} / \mathrm{m}^{3}, 32.1 \mu \mathrm{g} / \mathrm{m}^{3}, 22.7 \mu \mathrm{g} / \mathrm{m}^{3}$ and $10.9 \mu \mathrm{g} / \mathrm{m}^{3}$, respectively.

The final fit of the model was assessed using the Akaike information criterion (AIC) [53], and the residual
Table 2 Summary of daily hospital admissions for mental and behavioral disorders, meteorological variables and air pollutants in Curitiba, 2010-2016

\begin{tabular}{lllllll}
\hline Variable & Unit & Minimum & 25th & 50th & 75th & Maximum \\
\hline $\mathrm{SO}_{2}$ & $\mu \mathrm{g} / \mathrm{m}^{3}$ & 0 & 0.05 & 2.7 & 0.5 & 188.2 \\
$\mathrm{NO}_{2}$ & $\mu \mathrm{g} / \mathrm{m}^{3}$ & 5.0 & 23.5 & 39.2 & 32.1 & 114.2 \\
$\mathrm{O}_{3}$ & $\mu \mathrm{g} / \mathrm{m}^{3}$ & 0.3 & 14.4 & 28.3 & 22.7 & 81.4 \\
$\mathrm{PM}_{10}$ & $\mu \mathrm{g} / \mathrm{m}^{3}$ & 1.3 & 6.9 & 18.7 & 10.9 & 116.0 \\
$\mathrm{~T}$ & ${ }^{\circ} \mathrm{C}$ & 5.9 & 18.4 & 26.2 & 22.4 & 35.0 \\
$\mathrm{RH}$ & $\%$ & 39.0 & 75.5 & 87.8 & 81.8 & 99.9 \\
Men & hosp. & 0 & 1 & 2 & 2 & 29 \\
Women & hosp. & 0 & 0 & 1 & 1 & 20 \\
Young men & hosp. & 0 & 0 & 1 & 1 & 12 \\
Adult men & hosp. & 0 & 2 & 3 & 2 & 27 \\
Elderly men & hosp. & 0 & 0 & 1 & 1 & 6 \\
Young women & hosp. & 0 & 1 & 1 & 2 & 5 \\
Adult women & hosp. & 0 & 1 & 2 & 2 & 19 \\
Elderly women & hosp. & 0 & 0 & 1 & 1 & 6 \\
\hline
\end{tabular}

deviance $[54,55]$. For Poisson distribution the AIC was of 6717.3 and residual deviance of 4436.7. The quasiPoisson did not estimate AIC values, but the residual deviance was 4436.7. While the negative binomial presented AIC of 5291.9 and residual deviance of 1546.3. Therefore, the distribution that fitted the dataset was the negative binomial, which was used for the analyses.

Table 3 presents the results of the Stepwise method for each group, and their respective variables included in the final analysis. Additional results from the application of Stepwise method are presented as supplementary material. Considering the $p$-value $<0.05$ criterion, the $\mathrm{PM}_{10}$ concentration was significant only for groups of men, except for the elderly group. Fine particle concentrations are not measured regularly in the city, therefore not analyzed. In Brazil, only in the year 2018 the $\mathrm{PM}_{2.5}$ was included in the national air quality standard $\left(60 \mu \mathrm{g} / \mathrm{m}^{3}, 24 \mathrm{~h}\right)$.

Table 3 Variables selected by Stepwise method (significance level $a=0.05$ ) to compose the final model of each group

\begin{tabular}{lll}
\hline Groups & Variables & $\boldsymbol{p}$-value \\
\hline Men & $\mathrm{T}, \mathrm{SO}_{2}, \mathrm{NO}_{2}, \mathrm{O}_{3}, \mathrm{PM}_{10}$ & $<0.0001$ \\
Women & $\mathrm{T}, \mathrm{SO}_{2}, \mathrm{O}_{3}$ & $<0.0001$ \\
Young men (0-24 years old) & $\mathrm{T}, \mathrm{SO}_{2}, \mathrm{O}_{3}, \mathrm{PM}_{10}$ & $<0.0001$ \\
Adult men (25-59 years old) & $\mathrm{T}, \mathrm{SO}_{2}, \mathrm{NO}_{2}, \mathrm{O}_{3}, \mathrm{PM}_{10}$ & $<0.0001$ \\
Elderly men ( $\leq 60$ years old) & $\mathrm{T}, \mathrm{SO}_{2}, \mathrm{O}_{3}$ & $<0.0001$ \\
Young women (0-24 years old) & $\mathrm{T}, \mathrm{SO}_{2}, \mathrm{O}_{3}$ & $<0.0001$ \\
Adult women (25-59 years old) & $\mathrm{T}, \mathrm{SO}_{2}, \mathrm{O}_{3}$ & $<0.0001$ \\
Elderly women ( $\leq 60$ years old) & $\mathrm{T}, \mathrm{SO}_{2}, \mathrm{O}_{3}$ & $<0.0001$ \\
\hline
\end{tabular}




\section{Distributed lagged effects}

The GAM with random component given by negative binomial distribution was the one which best fitted the hospital admissions by MBD. The most significant RR was found in the lag 0 day for all groups analyzed, which means that environmental conditions rapidly affect individuals with MBD.

Table 4 shows the significant cumulative effects $(0-$ 7 days) of environmental variables on hospital admissions by MBD for men and women, which were adjusted according to the temporal trend, day of the week, relative humidity and air pollutant concentrations for each selected group. For men, lag 0 and lag 0-7 presented risk of exposure to environmental conditions, corresponding to 1.1911 (95\% CI: 1.14591.2399), and 1.0841 (95\% CI: $1.0816-1.1266)$, respectively. For women, the lag 0 , lags $0-6$ and $0-7$ also presented risks, although their values were lower. At lag 0 the RR value was 1.1891 (95\% CI: 1.15171.2290), and for the lag $0-6$ and lag $0-7$ were of 1.0647 (95\% CI: $1.0321-1.0992)$ and 1.0816 (95\% CI: 1.0487-1.1167), respectively.

In the final multivariable model of women's group, only the temperature, $\mathrm{SO}_{2}$ and $\mathrm{O}_{3}$ variables were selected by applying the Stepwise method. However, the pollutants were also a risk for $\mathrm{MBD}$ at lag 0 , showing an increase of 1.2 and $1.6 \%$, respectively for $\mathrm{SO}_{2}$ and $\mathrm{O}_{3}$ in hospitalizations by MBD. In case of temperature, the RR value was 1.0407 (95\% CI: 1.0230-1.0587) for women.

For men, despite the range of pollutants selected by the model, only $\mathrm{NO}_{2}$ present a RR of 1.0175 (95\% CI: 1.0105-1.0246) in lag 0 , besides air temperature (RR 1.0182, 95\% CI: 1.0009-1.0357). In contrast, the women's group presented a risk associated with all pollutants selected for the multivariable model, as presented in Table 4.

The values of RR for groups stratified by sex and age are show in Table 5. The environmental conditions

Table 4 Relative risks with 95\% confidence interval (in parentheses) of hospital admissions due to mental and behavioral disorders associated with daily mean temperature vs reference temperature $\left(22.4^{\circ} \mathrm{C}\right)$ and air pollutants concentrations by sex

\begin{tabular}{lll}
\hline- & Men & Women \\
\hline Lag 0 & $1.1911(1.1459-1.2399)$ & $1.1891(1.1517-1.2290)$ \\
Lag 0-6 & - & $1.0647(1.0321-1.0992)$ \\
Lag 0-7 & $1.0841(1.0446-1.1266)$ & $1.0816(1.0487-1.1167)$ \\
$\mathrm{NO}_{2}{ }^{\mathrm{a}}$ & $1.0175(1.0105-1.0246)$ & - \\
$\mathrm{SO}_{2}{ }^{\mathrm{a}}$ & - & $1.0121(1.0029-1.0123)$ \\
$\mathrm{O}_{3}{ }^{\mathrm{a}}$ & - & $1.0161(1.0087-1.0236)$ \\
$\mathrm{T}^{\mathrm{a}}$ & $1.0182(1.0009-1.0357)$ & $1.0407(1.0230-1.0587)$ \\
\hline
\end{tabular}

${ }^{\mathrm{a}}$ Relative risk at lag 0 presented pronounced $R R$ at lag 0 day for all age groups (young, adult and elderly), and sexes. The RR values for men's groups were higher than women, except for the young group. For young women group the RR was of 1.1987 (95\% CI: 1.1191-12,892) at lag 0 day, while for young men group was of 1.1400 (95\% CI: 1.05511.2366). Among age groups, the adult group was susceptible to air pollutants and temperature variation, with women groups being more affected by air pollutants than men. Ozone was a risk for all women groups, and even higher for the young group, with RR of 1.0319 (95\% CI: 1.0165-1.0483).

Air temperature was the environmental variable with highest RR at lag 0 day for all ages and sexes analyzed. Therefore, the behavior of RR as a function of temperature was deeply analyzed. Figures 2 and 3, for men and women, respectively, show the exposureresponse curves of mean temperature and the significant risks on hospital admissions by MBD for all groups analyzed at lag 0 day. The exposure-response curves were different among groups of men analyzed. In the young group, significant $R R$ were found for temperatures above $22.4^{\circ} \mathrm{C}$, and also for lower temperatures, with a peak risk at $15.7^{\circ} \mathrm{C}$. On the other hand, for adult group significant RR were found only for elevated temperatures above $22.4{ }^{\circ} \mathrm{C}$ (percentile 50th), while for elderly group air temperature was a risk for almost the entire range, except around mean daily temperature. The groups of young and elderly men presented significant differences in the behavior and values, when compared with the curve for all men (Fig. 2a), indicating the relevance of age on hospital admissions by MBD, with young and elderly groups being the most affected.

For the women groups the exposure-response curves also presented differences, although they were less pronounced when compared with men. For elderly group air temperature represented a risk for almost the whole range, except around mean daily temperature, while for all women and adult group the risk increases significantly in case of extremely high temperatures, above $30^{\circ} \mathrm{C}$ (Fig. 3a and c).

\section{Discussion}

In Brazil, there are several studies addressing the association between hospitalization and deaths by cardiorespiratory diseases with air quality and meteorological variables [56-58]. However, concerning the hospital admissions by mental and behavioral disorders, and their association with environmental conditions (air pollution and temperature) the studies are very limited. To our knowledge, this is the first epidemiological study addressing the association between temperature and air 
Table 5 Relative risks with 95\% confidence interval (in parentheses) of hospital admissions due to mental and behavioral disorders associated with daily mean temperature vs reference temperature $\left(22.4^{\circ} \mathrm{C}\right)$ and air pollutants concentrations stratified by sex and age

\begin{tabular}{|c|c|c|c|}
\hline & Young men & Adult men & Elderly men \\
\hline Lag 0 & $1.1400(1.0551-1.2366)$ & $1.2102(1.1573-1.2679)$ & 1.1877 (1.0548-1.3559) \\
\hline Lag 0-1 & - & $1.0496(1.0056-1.0969)$ & - \\
\hline Lag 0-7 & - & $1.0864(1.0397-1.1371)$ & $1.1306(1.0032-1.2868)$ \\
\hline $\mathrm{NO}_{2}{ }^{\mathrm{a}}$ & - & $1.0181(1.0101-1.00263)$ & - \\
\hline $\mathrm{T}$ & $1.0133(1.0105-1.0479)$ & $1.0225(1.0025-1.0428)$ & $1.0215(1.0195-1.07161)$ \\
\hline- & Young women & Adult women & Elderly women \\
\hline Lag 0 & $1.1987(1.1191-1.2892)$ & $1.1904(1.1499-1.2337)$ & 1.1209 (1.0348-1.2184) \\
\hline Lag 0-1 & - & $1.0419(1.0047-1.0818)$ & - \\
\hline Lag 0-6 & - & $1.0683(1.0325-1.1063)$ & - \\
\hline Lag 0-7 & - & $1.0829(1.0472-1.1212)$ & $1.0993(1.0207-1.1867)$ \\
\hline $\mathrm{SO}_{2}{ }^{\mathrm{a}}$ & - & $1.0126(1.0024-1.0249)$ & - \\
\hline $\mathrm{O}_{3}{ }^{\mathrm{a}}$ & $1.0319(1.0165-1.0483)$ & $1.0241(1.0169-1.0315)$ & $1.0198(1.0034-1.0367)$ \\
\hline$T^{a}$ & $1.0598(1.0195-1.1027)$ & $1.0543(1.0374-1.0717)$ & $1.0651(1.0213-1.1117)$ \\
\hline
\end{tabular}

${ }^{a}$ Relative risk at lag 0

pollutants concentrations with hospital admissions for MBD in Brazil.

The cumulative short-term effects of air pollutants, temperature and relative humidity on hospitalization by MBD for men and women groups were investigated in this work. The quasi-Poisson model is widely used [19, $21,22]$, however, in our analysis and based on AIC results, a best fit to dataset was obtained by the Negative Binomial model, as found by [33]. The different models used in the studies available in the literature make it difficult to compare the results, although it is important to evaluate the adequacy of the model to the dataset, which could lead to misinterpretation of results, such as overestimation of RR.

Montero [59] emphasize the importance to analyze separately temperature and relative humidity, since these variables are correlated. Relative humidity did not present any risk in this study, probably because there was a slight variation of this variable over the period. Therefore, due to its low variability, humidity is rarely the explicit focus in health impact studies, despite its physiological importance $[60,61]$. In the same way, other environmental variables could be correlated, and should be corrected, this potential multicollinearity, as performed in this and previous works [21, 62].

We found significant impacts of environmental variables on hospitalization by MBD, with differences between men and women, as well as among different age groups. At lag 0 the RR for all environmental variables were higher for men than women, except for young group [63]. observed a greater number of significant associations for women than men exposed to gaseous pollutants, as obtained in the present study. $\mathrm{PM}_{10}$ concentrations were not statistically significant and therefore were not included in the final model for women. It is important to note that fine particles concentrations could not be analyzed, which are those with stronger evidences of causality [22, 64, 65].

Air pollution may exert adverse effects on central nervous system function [12], with men and women reacting differently to this exposure [66]. For example [67], ,have shown that exposure to $\mathrm{O}_{3}$ is associated with the reduced performance of cognitive activities, such as short-term memory and coding skills. This is consistent with our observations that $\mathrm{O}_{3}$ was found as a significant variable, and also a risk for women. Elevation of the level of free radicals related to $\mathrm{O}_{3}$ exposure to affects neurodegenerative processes causing oxidative stress, which alters the brain structures $[68,69]$.

Lin [70] also observed the influence of sex on sensitivity to types of pollutants, i.e., the men exhibited sensitivity to particulate matter, while women to $\mathrm{NO}_{2}$; and proposed, as an explanation, the difference on physiological characteristics. The behavior of each gender is also an important factor, since the activities of each individual (for example, cooking, cleaning, lawn care) produce different exposure patterns [71]. In contrast [6], did not found significant differences in the association between sex and age groups for Shanghai, China.

Studies concerning neurodegenerative disorders indicated difference on prevalence and severity of these disorders between the two sexes [17, 18, 72, 73]. Ullah [18] pointed out that these disorders are influenced by genetic and lifestyle factors, concurrent health conditions as 

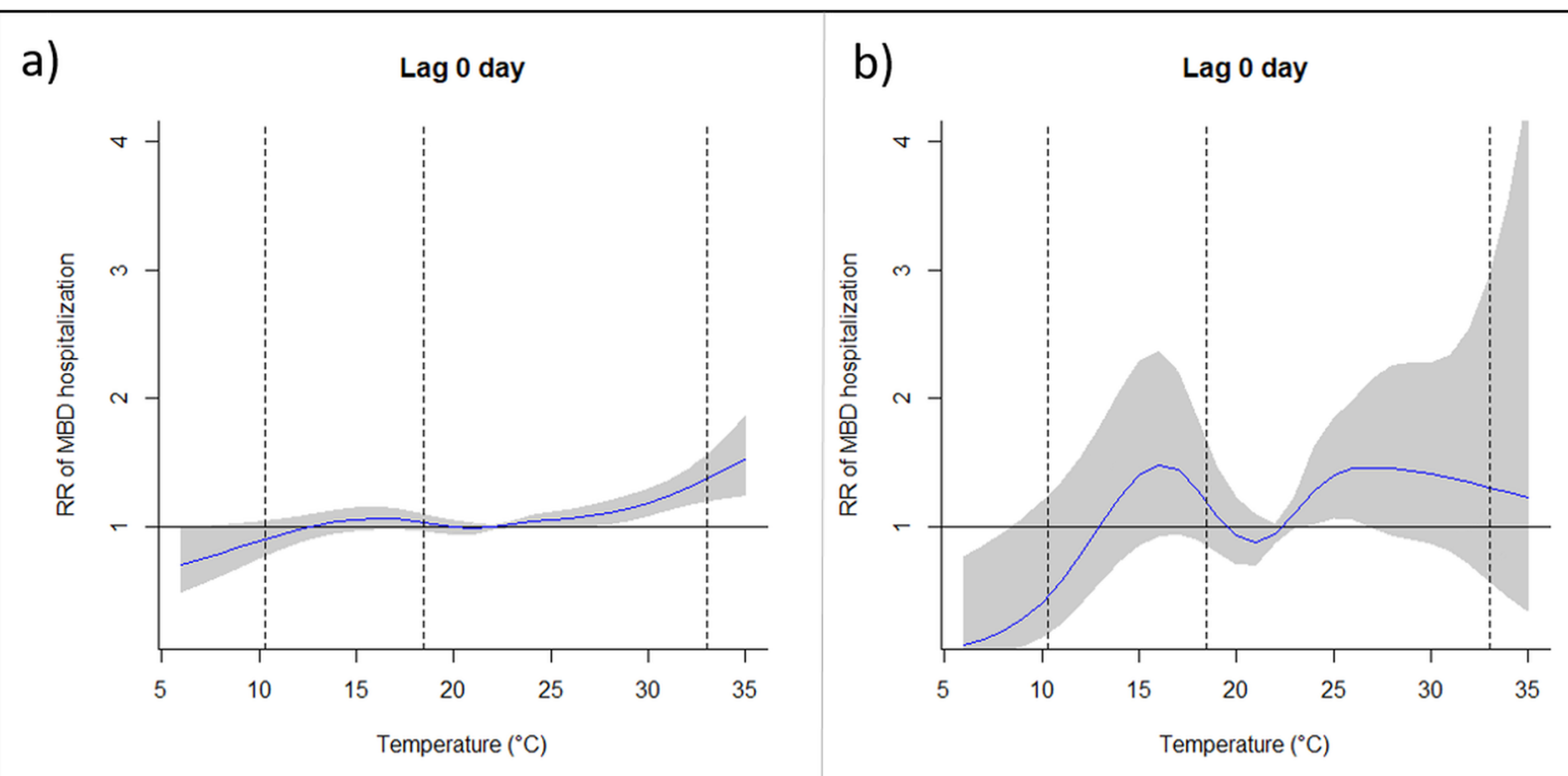

c)

Lag 0 day

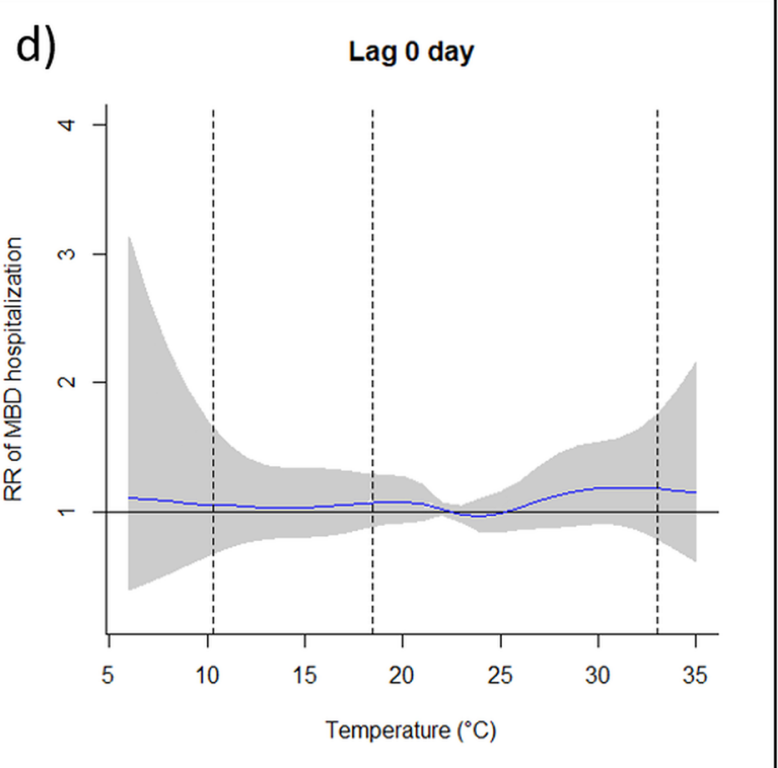

Fig. 2 Exposure-response curve of mean temperature $\left({ }^{\circ} \mathrm{C}\right)$ and relative risk for mental and behavioral disorder (reference temperature at $22.4^{\circ} \mathrm{C}$ ) for men. a. Group of all men. b. Group of young men. c. Group of adult men. d. Group of elderly men. Vertical lines mean the 1st, 25th and 99th percentiles

well as un-modifiable predisposing risk factors, including gender and age.

Among environmental variables analyzed $\left(\mathrm{O}_{3}, \mathrm{NO}_{2}\right.$, $\mathrm{SO}_{2}, \mathrm{PM}_{10}$, temperature and relative humidity), air temperature presented the highest RR for hospitalization by $\mathrm{MBD}$ at lag 0 . The RR for temperature at lag 0 day was higher for women than men (RR at Table 5), as also found by [20], and suggested by [19]. We found differences among age groups analyzed, with elderly being more affected and higher RR to temperature exposure at lag 0 .
The exposure-response curves of temperature in this work differ from those obtained for Lisbon [20]. Our results, analyzing also the cumulative effects, indicated that hospital admissions increase significantly with high and also low temperatures, especially for young men group (the curves for all significant lags and considering all groups are provided as supplementary material). In addition, for elderly groups temperature is a risk for almost all range, except around comfortable temperature, i.e., the mean daily temperature $\left(22.4^{\circ} \mathrm{C}\right)$. Biological 


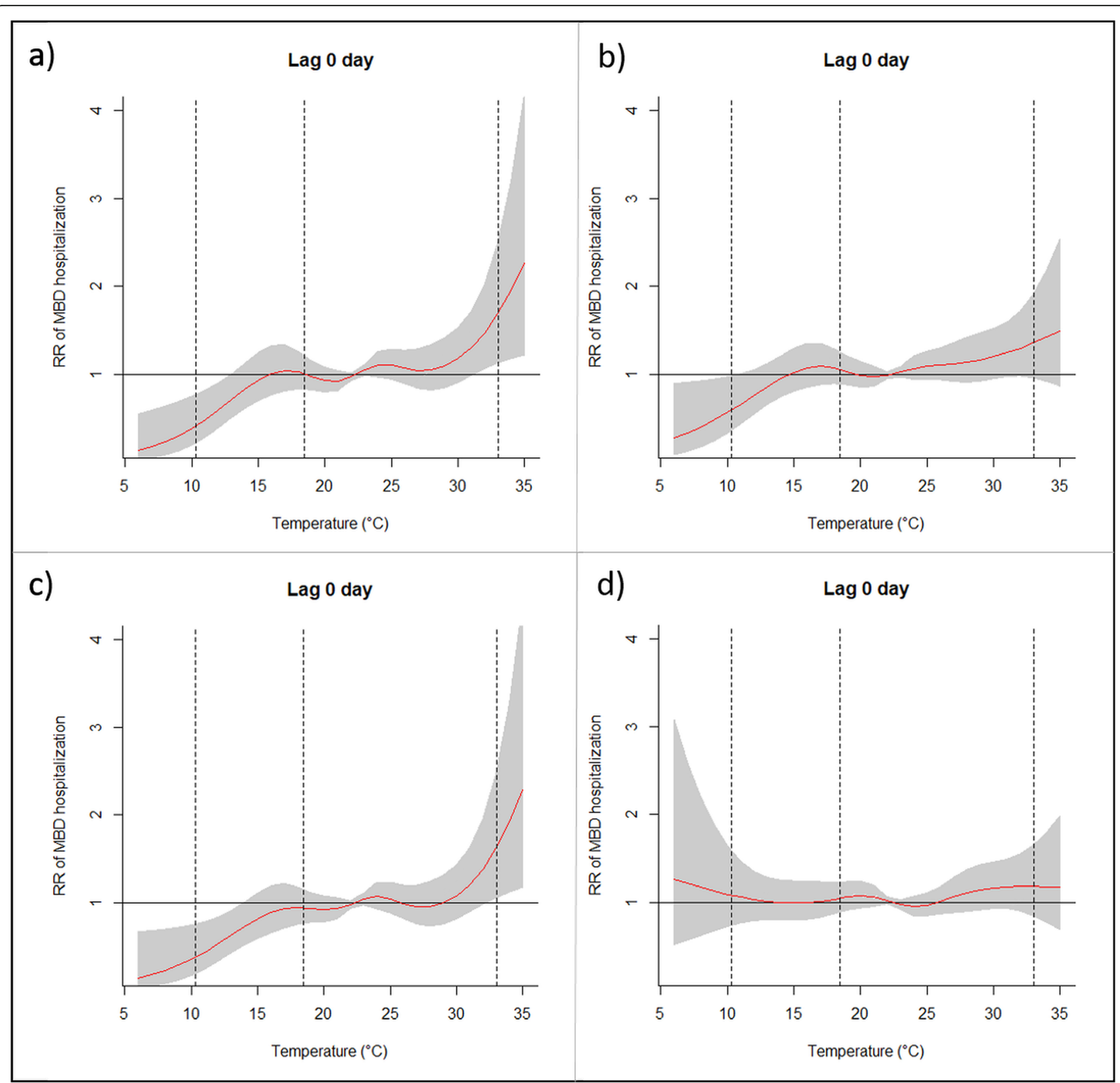

Fig. 3 Exposure-response curve of mean temperature $\left({ }^{\circ} \mathrm{C}\right.$ ) and relative risk for mental and behavioral disorder (reference temperature at $22.4^{\circ} \mathrm{C}$ ) for women. a. Group of all women. b. Group of young women. c. Group of adult women. d. Group of elderly women. Vertical lines mean the 1st, 25th and 99th percentiles

factors can explain this behavior, since the thermoregulatory system with ageing decreases the ability to regulate the core body temperature $[74,75]$.

\section{Conclusions}

The present study showed significant associations between the environmental conditions $\left(\mathrm{SO}_{2}, \mathrm{NO}_{2}, \mathrm{O}_{3}\right.$ and $\mathrm{PM}_{10}$, temperature and relative humidity) and hospitalizations by mental and behavioral disorders. The effects were immediate and non-linear. Temperature was the variable responsible for the most pronounced increase in the risk of hospital admissions by MBD, affecting men and women differently, as well as the age groups.

The synergistic association of air pollutants and temperature affected more men than women, except for the young group of men. Among age groups, the adult group was more susceptive to air pollutants and temperature, with women being more affected by air pollutants than men. In addition, the individual effect of temperature was more pronounced among women of all age groups. Finally, the elderly of both sexes were the most susceptible to temperature variability. From results 
obtained in this study, it can be pointed out the necessity of public policies to control the atmospheric emissions, as well as for adaptation to global climate change.

\section{Supplementary information}

Supplementary information accompanies this paper at https://doi.org/10. 1186/s12940-020-00606-W.

Additional file 1 : Figure S1: Exposure-response curve of ean temperature $\left({ }^{\circ} \mathrm{C}\right)$ ad cumulative relative risk for mental and behavioral disorder (reference temperature at $22.4^{\circ} \mathrm{C}$ ) for men. a. Group of all men. b. Group of young men. c. Group of adult men. d. Group of elderly men. Vertical lines correspond to the 1st, 25th and 99th temperature percentiles. Figure $\mathbf{S 2}$ Exposure-response curve of mean temperature $\left({ }^{\circ} \mathrm{C}\right)$ and cumulative relative risk for mental and behavioral disorder (reference temperature at $22.4^{\circ} \mathrm{C}$ ) for women. a. b. Group of all women. c. d. e. Group of adult women. f. Group of elderly women. Vertical lines correspond to the 1st, 25th and 99th temperature percentiles. The Stepwise method is a procedure for selecting or deleting variables from a model. It is based on an algorithm that checks the importance of variables, including or excluding them from the model based on a decision rule. The importance of the variable is defined in terms of a measure of statistical significance of the coefficient associated with the variable for the model. Table S1 $P$-value used by the method (significance level $a=0.05$ ) for selection of variables in the final model of each group.

\section{Abbreviations}

AIC: Akaike information criterion; CAPES: Coordenação de Aperfeiçoamento de Pessoal de Nível Superior; Cl: Confidence interval; CNPq: Conselho Nacional de Desenvolvimento Científico e Tecnológico; DATASUS: Computer Science Department of the Unified Health System; df: degrees of freedom; DLNM: Distributed lag non-linear model; GAM: Generalized additive model; IAP: Environmental Institute of Parana; ICD: Internal Classification of Diseases; MBD: Mental and behavioral disorders; $\mathrm{NO}_{2}$ : Nitrogen dioxide; $\mathrm{O}_{3}$ : Ozone; $\mathrm{PM}_{10}$ : Particulate material 10; $\mathrm{PM}_{2.5}$ : Particulate material 2.5; RR: Relative risk; $\mathrm{SO}_{2}$ : Sulfur dioxide; SUS: Single System of Health

\section{Acknowledgments}

The authors would like to acknowledge the Parana Environmental Institute (Instituto Ambiental do Paraná - IAP) and DATASUS for providing the dataset.

\section{Authors' contributions}

Conceptualization: IS, DSA and LDM; Methodology: IS and EMH; Writing: IS, LDM, DSA, EMH; Funding Acquisition: LDM, MLG; Supervision: LDM and EMH. All authors read and approved the final manuscript.

\section{Funding}

National Council for Scientific and Technological Development (Conselho Nacional de Desenvolvimento Científico e Tecnológico - CNPq), process306862/2018-2. This study was financed in part by the Coordination for the Improvement of Higher Education Personnel (Coordenação de Aperfeiçoamento de Pessoal de Nível Superior - CAPES), finance Code 001.

\section{Availability of data and materials}

The dataset used and/or analyzed in this study are available online or under requested at public institutions: Datasus (www.datasus.saude.gov.br) and IAP (www.iap.pr.gov.br).

\section{Consent for publication}

Not applicable.

\section{Competing interests}

The authors declare that they have no competing interests.

\section{Author details}

${ }^{1}$ Federal University of Technology - Paraná, Av. dos Pioneiros, 3131, Londrina, PR 86036-370, Brazil. ² State University of Maringa, Av. Colombo, 5790 - Vila Esperança, Maringá, PR 87020-900, Brazil.
Received: 11 June 2019 Accepted: 11 May 2020

Published online: 06 July 2020

\section{References}

1. Costello A, Abbas M, Allen A, Ball S, Bell S, Bellamy R, et al. Managing the health effects of climate change. Lancet. 2009;373(9676):1693-733 Available from: https://linkinghub.elsevier.com/retrieve/pii/S0140673609609351.

2. Landrigan PJ, Fuller R, Acosta NJR, Adeyi O, Arnold R, Basu N (Nil), et al. The Lancet Commission on pollution and health. Lancet. 2017;391(10119):462512.

3. World Health Organization 2016. Fact Sheet on Mental Disorders. Fact Sheet on Mental Disorders. 2016. http://www.who.int/mediacentre/factsheets/fs3 96/e.

4. MacCORMAC B. In: MacCORMAC B, editor. Introductionto the scientific study of atmospheric pollution. 1st ed. Palo Alto: Reidel Publishing Company; 1971. p. 175.

5. Power MC, Adar SD, Yanosky JD, Weuve J. Exposure to air pollution as a potential contributor to cognitive function, cognitive decline, brain imaging, and dementia: a systematic review of epidemiologic research. Neurotoxicology. 2016;56:235-53. Available from:. https://doi.org/10.1016/j. neuro.2016.06.004

6. Chen H, Kwong JC, Copes R, Tu K, Villeneuve PJ, van Donkelaar A, et al. Living near major roads and the incidence of dementia, Parkinson's disease, and multiple sclerosis: a population-based cohort study. Lancet. 2017; 389(10070):718-26.

7. Costa RL. Cenários Futuros de Mudanças Climáticas e Impactos do Conforto Térmico Humano em Áreas Urbanizadas (T); 2017.

8. Schikowski T, Vossoughi M, Vierkötter A, Schulte T, Teichert T, Sugiri D, et al. Association of air pollution with cognitive functions and its modification by APOE gene variants in elderly women. Environ Res. 2015;142:10-6. Available from:. https://doi.org/10.1016/j.envres.2015.06.009.

9. Block ML, Calderón-Garcidueñas L. Air pollution: mechanisms of neuroinflammation and CNS disease. Trends Neurosci. 2009;32(9):506-16.

10. Buoli M, Grassi S, Caldiroli A, Carnevali GS, Mucci F, lodice S, et al. Is there a link between air pollution and mental disorders? Environ Int. 2018:118(May): 154-68. Available from. https://doi.org/10.1016/j.envint.2018.05.044.

11. Kasdagli Ml, Katsouyanni K, Dimakopoulou K, Samoli E. Air pollution and Parkinson's disease: a systematic review and meta-analysis up to 2018. Int J Hyg Environ Health. 2019;222(3):402-9. Available from. https://doi.org/10. 1016/j.ijheh.2018.12.006

12. Kilian J, Kitazawa M. The emerging risk of exposure to air pollution on cognitive decline and Alzheimer's disease - evidence from epidemiological and animal studies. Biomed J. 2018;41(3):141-62. Available from. https://doi. org/10.1016/j.bj.2018.06.001.

13. Chin-Chan M, Navarro-Yepes J, Quintanilla-Vega B. Environmental pollutants as risk factors for neurodegenerative disorders: Alzheimer and Parkinson diseases. Front Cell Neurosci. 2015;9(April):1-22.

14. Moulton PV, Yang W. Air pollution, oxidative stress, and Alzheimer's disease J Environ Public Health. 2012;2012(x):1-9.

15. Brockmeyer S, D'Angiulli A. How air pollution alters brain development: the role of neuroinflammation. Transl Neurosci. 2016;7(1):24-30

16. Calderón-Garciduenãs L, Vojdani A, Blaurock-Busch E, Busch Y, Friedle A Franco-Lira $M$, et al. Air pollution and children: neural and tight junction antibodies and combustion metals, the role of barrier breakdown and brain immunity in neurodegeneration. J Alzheimers Dis. 2015;43(3):1039-58.

17. Becker JB, McClellan ML, Reed BG. Sex differences, gender and addiction. J Neurosci Res. 2017;95(1-2):136-47.

18. Ullah MF, Ahmad A, Bhat SH, Abu-Duhier FM, Barreto GE, Ashraf GM. Impact of sex differences and gender specificity on behavioral characteristics and pathophysiology of neurodegenerative disorders. Neurosci Biobehav Rev. 2019; Available from: https://www.sciencedirect.com/science/article/pii/S014 976341830811X?dgcid=rss_sd_all.

19. Peng Z, Wang $Q$, Kan $H$, Chen $R$, Wang W. Effects of ambient temperature on daily hospital admissions for mental disorders in Shanghai, China: a time-series analysis. Sci Total Environ. 2017:590-591:281-6. Available from: https://doi.org/10.1016/j.scitotenv.2017.02.237

20. Almendra R, Loureiro A Silva G, Vasconcelos J Santana P. Short-term impacts of air temperature on hospitalizations for mental disorders in Lisbon. Sci Total Environ. 2019;647:127-33. Available from. https://doi.org/10. 1016/j.scitotenv.2018.07.337. 
21. Rodrigues $M$, Santana $P$, Rocha $A$. Effects of extreme temperatures on cerebrovascular mortality in Lisbon: a distributed lag non-linear model. Int J Biometeorol. 2019:549-59. Available from:. https://doi.org/10.1007/s00484019-01685-2.

22. Lee S, Lee H, Myung W, Kim EJ, Kim H. Mental disease-related emergency admissions attributable to hot temperatures. Sci Total Environ. 2018:616617:688-94. Available from. https://doi.org/10.1016/j.scitotenv.2017.10.260.

23. Shin J, Park JY, Choi J. Long-term exposure to ambient air pollutants and mental health status: a nationwide population-based cross-sectional study. PLoS One. 2018;13(4):1-12.

24. Tzivian L, Dlugaj M, Winkler A, Weinmayr G, Hennig F, Fuks KB, et al. Longterm air pollution and traffic noise exposures and mild cognitive impairment in older adults: a cross-sectional analysis of the Heinz Nixdorf recall study. Environ Health Perspect. 2016;124(9):1361-8.

25. Oudin A, Forsberg B, Adolfsson AN, Lind N, Modig L, Nordin M, et al. Trafficrelated air pollution and dementia incidence in northern Sweden: a longitudinal study. Environ Health Perspect. 2016;124(3):306-12. Available from:. https://doi.org/10.1289/ehp.1408322.

26. Bando DH, Teng CT, Volpe FM, de Masi E, Pereira LA, Braga AL. Suicide and meteorological factors in São Paulo, Brazil, 1996-2011: a time series analysis. Rev Bras Psiquiatr. 2017;39(3):220-7.

27. Boff MS, Sekyia FS, Machado De Campos Bottino C. Prevalence of dementia among brazilian population: systematic review Revisão sistemática sobre prevalência de demência entre a população brasileira. Rev Med. 2015;94(154): 154-61. Available from:. https://doi.org/10.11606/issn.1679-9836.v.94i3p154-161.

28. Ferretti C, Sarti FM, Nitrini R, Ferreira FF, Brucki SMD. An assessment of direct and indirect costs of dementia in Brazil. PLoS One. 2018;13(3):1-15.

29. IBGE. Panorama Curitiba. 2018. https://cidades.ibge.gov.br/brasil/pr/curitiba/ pan. Available from: https://cidades.ibge.gov.br/brasil/pr/curitiba/panorama. Cited 2019 Mar 25

30. IPARDES. Cadernos Ipardes. 2018. http://www.ipardes.pr.gov.br/ojs/index. php/caderno.

31. Krüger EL, Minella FO, Rasia F. Impact of urban geometry on outdoor thermal comfort and air quality from field measurements in Curitiba, Brazil. Build Environ. 2011;46(3):621-34.

32. Alvares CA, Stape JL, Sentelhas PC, De Moraes Gonçalves JL, Sparovek G. Köppen's climate classification map for Brazil. Meteorol Zeitschrift. 2013; 22(6):711-28.

33. Ardiles LG, Tadano YS, Costa S, Urbina V, Capucim MN, da Silva I, et al. Negative binomial regression model for analysis of the relationship between hospitalization and air pollution. Atmos Pollut Res. 2017;9(2):33341. Available from:. https://doi.org/10.1016/j.apr.2017.10.010.

34. de Miranda RM, de Fatima AM, Fornaro A, Astolfo R, de Andre PA, Saldiva P. Urban air pollution: a representative survey of PM 2.5 mass concentrations in six Brazilian cities. Air Qual Atmos Heal. 2012;5(1):63-77.

35. Bakonyi SMC, Danni-Oliveira IM, Martins LC, Braga ALF. Air pollution and respiratory diseases among children in Brazil. Rev Saude Publica / J Public Heal. 2004;38(5):5 Available from: http://www.popline.org/node/242055.

36. Zhang Z. Variable selection with stepwise and best subset approaches. Ann Transl Med. 2016:4(7):136.

37. Sharma MJ, Yu SJ. Stepwise regression data envelopment analysis for variable reduction. Appl Math Comput. 2015;253:126-34. Available from: https://doi.org/10.1016/j.amc.2014.12.050.

38. Ghisletta P, Renaud O, Fagot D, Lecerf T, de Ribaupierre A. Age and sex differences in intra-individual variability in a simple reaction time task. Int J Behav Dev. 2018;42(2):294-9.

39. Belsky DW, Caspi A, Cohen HJ, Kraus WE, Ramrakha S, Poulton R, et al. Impact of early personal-history characteristics on the pace of aging: implications for clinical trials of therapies to slow aging and extend healthspan. Aging Cell. 2017;16(4):644-51.

40. Kanasi E, Ayilavarapu S, Jones J. The aging population: demographics and the biology of aging. Periodontol 2000. 2016;72(1):13-8.

41. Gasparrini A, Guo Y, Hashizume M, Lavigne E, Zanobetti A, Schwartz J, et al. Mortality risk attributable to high and low ambient temperature: a multicountry observational study. Lancet. 2015;386(9991):369-75.

42. Gasparrini A, Armstrong B, Kenward MG. Distributed lag non-linear models. Stat Med. 2010;29(21):2224-34.

43. Tong L, Li K, Zhou Q. Season, sex and age as modifiers in the association of psychosis morbidity with air pollutants: a rising problem in a Chinese metropolis. Sci Total Environ. 2016;541(2):928-33. Available from:. https://doi. org/10.1016/j.scitotenv.2015.09.066.
44. Wang X, Lavigne E, Ouellette-Kuntz H, Chen BE. Acute impacts of extreme temperature exposure on emergency room admissions related to mental and behavior disorders in Toronto, Canada. J Affect Disord. 2014;155(1):15461. Available from:. https://doi.org/10.1016/j.jad.2013.10.042.

45. Islam SKM, Rasooly MH. Prevalence and risk factors associated with obesity among adult Kabul citizens (Afghanistan), 2012. ljdo. 2012;4(4):152-60 Available from: http://ijdo.ssu.ac.ir/article-1-106-en.html.

46. Lim Y, Kim H, Kim J, Bae S, et al. HP-E health, 2012 undefined. Air pollution and symptoms of depression in elderly adults. EhpNiehsNihGov. 2012;120(7): 1023-8. Available from:. https://doi.org/10.1289/ehp.1104100.

47. Szyszkowicz M. Air pollution and emergency department visits for depression in Edmonton, Canada. Int J Occup Med Environ Health. 2007; 20(3):241-5

48. Vida S, Durocher M, Ouarda TBMJ, Gosselin P. Relationship between ambient temperature and humidity and visits to mental health emergency departments in Québec. Psychiatr Serv. 2012;63(11):1150-3.

49. Hastie T, Tibshirani R. Varying-coefficient models. J R Stat Soc Ser B. 1993;55: 757-79.

50. Cui L, Geng X, Ding T, Tang J, Xu J, Zhai J. Impact of ambient temperature on hospital admissions for cardiovascular disease in Hefei City, China; 2019.

51. Wedderburn RW. Quasi-likelihood functions, generalized linear models, and the gauss - Newton method. Biometrika. 1974;61:439-47.

52. Hastie T, Robert T. Generalized additive models 1 introduction 2 smoothing methods and generalized addi- tive models. Prev Med (Baltim). 1990;43.

53. Aikaike H. A new look at the statistical model identification. IEEE Trans Automat Contr. 1974;AC-19(6):716-23.

54. Mccullagh P, Nelder JA. Generalized linear models, vol. 2; 1989. p. 85.

55. Paula GA. Modelo de regressão com apoio computacional; 2010. p. 403. Available from: http://www.ime.usp.br/?giapaula/mlgs.html.

56. Ferreira TM, Forti MC, de Freitas CU, Nascimento FP, Junger WL, Gouveia N. Effects of particulate matter and its chemical constituents on elderly hospital admissions due to circulatory and respiratory diseases. Int J Environ Res Public Health. 2016;13(10):1-11

57. Ikefuti PV, Barrozo LV, Braga ALF. Mean air temperature as a risk factor for stroke mortality in São Paulo, Brazil. Int J Biometeorol. 2018;62(8):1535-42.

58. Levin RK, Katz M, Saldiva PHN, Caixeta A, Franken M, Pereira C, et al. Increased hospitalizations for decompensated heart failure and acute myocardial infarction during mild winters: a seven-year experience in the public health system of the largest city in Latin America. PLoS One. 2018; 13(1):1-10.

59. Montero JC, Mirón IJ, Criado-Álvarez JJ, Linares C, Díaz J. Influence of local factors in the relationship between mortality and heat waves: Castile-La Mancha (1975-2003). Sci Total Environ. 2012;414:73-80. Available from:. https://doi.org/10.1016/j.scitotenv.2011.10.009.

60. Liu T, Kang M, Zhang B, Xiao J, Lin H, Zhao Y, et al. Independent and interactive effects of ambient temperature and absolute humidity on the risks of avian influenza a(H7N9) infection in China. Sci Total Environ. 2018; 619-620(160): 1358-1365. Available from: https://doi.org/10.1016/j.scitotenv. 2017.11.226.

61. Davis RE, McGregor GR, Enfield KB. Humidity: a review and primer on atmospheric moisture and human health. Environ Res. 2016;144:106-16.

62. Slinker BK, Glantz SA. Multiple regression for physiological data analysis: the problem of multicollinearity. Am J Physiol Integr Comp Physiol. 2017;249(1): R1-12.

63. Luginaah IN, Fung KY, Gorey KM, Webster G, Wills C. Association of ambient air pollution with respiratory hospitalization in a government-designated "area of concern": the case of Windsor. Ontario Environ Health Perspect. 2005;113(3):290-6.

64. Chen H, Kwong JC, Copes R, Hystad P, van Donkelaar A, Tu K, et al. Exposure to ambient air pollution and the incidence of dementia: a population-based cohort study. Environ Int. 2017;108(May):271-7. Available from. https://doi.org/10.1016/j.envint.2017.08.020.

65. Qiu H, Zhu X, Wang L, Pan J, Pu X, Zeng X, et al. Attributable risk of hospital admissions for overall and specific mental disorders due to particulate matter pollution: a time-series study in Chengdu, China. Environ Res. 2019: 230-7. Available from. https://doi.org/10.1016/j.envres.2018.12.019.

66. Power MC, Weisskopf MG, Alexeeff SE, Coull BA, Avron S, Schwartz J. Trafficrelated air pollution and cognitive function in a cohort of older men. Environ Health Perspect. 2011;119(5):682-7.

67. Chen JC, Schwartz J. Neurobehavioral effects of ambient air pollution on cognitive performance in US adults. Neurotoxicology. 2009;30(2):231-9. 
68. Calderón-Garcidueñas L, Mora-Tiscareño A, Ontiveros E, Gómez-Garza G, Barragán-Mejía G, Broadway J, et al. Air pollution, cognitive deficits and brain abnormalities: a pilot study with children and dogs. Brain Cogn. 2008; 68(2):117-27. Available from:. https://doi.org/10.1016/j.bandc.2008.04.008.

69. Dorado-Martínez C, Paredes-Carbajal C, Mascher D, Borgonio-Pérez G, RivasArancibia S. Effects of different ozone doses on memory, motor activity and lipid peroxidation levels, in rats. Int J Neurosci. 2001;108(3-4):149-61.

70. Lin M. Coarse particulate matter and hospitalization for respiratory infections in children younger than 15 years in Toronto: a case-crossover analysis. Pediatrics. 2005;1 16(2):e235-40.

71. Berhane K, Gauderman WJ, Stram DO, Thomas DC. Statistical issues in studies of the long-term effects of air pollution: the Southern California children?S health study. Stat Sci. 2005;19(3):414-49.

72. Ngun TC, Ghahramani N, Sánchez FJ, Bocklandt S, Vilain E. The genetics of sex differences in brain and behavior. Front Neuroendocrinol. 2013;32(2): 227-46.

73. Yanguas-Casas N. SM gr up neurological disorders and stroke sex Di ff erences in neurodegenerative. SMGroup. 2017;3(1):1-6 Available from: http://www.ncbi.nlm.nih.gov/entrez/query.fcgi?cmd=Retrieve\&db= PubMed\&dopt=Citation\&list_uids=19507495.

74. Guarente L, Kenyon C. Genetic pathways that regulate ageing in model organisms. Nature. 2000;408(6809):255-62.

75. Blatteis CM. Age-dependent changes in temperature regulation - a mini review. Gerontology. 2012;58(4):289-95.

\section{Publisher's Note}

Springer Nature remains neutral with regard to jurisdictional claims in published maps and institutional affiliations.

Ready to submit your research? Choose BMC and benefit from:

- fast, convenient online submission

- thorough peer review by experienced researchers in your field

- rapid publication on acceptance

- support for research data, including large and complex data types

- gold Open Access which fosters wider collaboration and increased citations

- maximum visibility for your research: over $100 \mathrm{M}$ website views per year

At $\mathrm{BMC}$, research is always in progress.

Learn more biomedcentral.com/submissions 